\title{
BCL2 Gene Rearrangement
}

National Cancer Institute

\section{Source}

National Cancer Institute. BCL2 Gene Rearrangement. NCI Thesaurus. Code C132019.

A molecular abnormality indicating rearrangement of the BCL2 gene. 